\title{
Standar Pengambilan Keputusan Secara Kritis Oleh Perawat Dalam Pelayanan Kesehatan
}

\author{
Emyranda Samosir
}

\section{emyrandasamosir@gmail.com}

\begin{abstract}
Pemberian asuhan keperawatan harus memeperhatikan klien dengan memberikan penghargaan individu meliputi preferensi, keperluan, nilai-nilai, dan memastikan bahwa semua pengambilan keputusan klinik telah mempertimbangkan dari semua nilai-nilai yang diingini pasien (Comite if quality of health institute of medicine 2001). Pelaksanaan proses keperawatan ini dibutuhkan kemampuan perawat dalam mengambil keputusan klinis dan tanpa mengesampingkan nilai disiplin etik dan bioetik keperawatan. Sehingga dalam proses ini perawat harus melibatkan pasien.Beberapa konsep yang digunakan untuk menggambarkan berpikir kritis dalam keperawatan adalah penalaran klinis, perumusan diagnostik, pengambilan keputusan, penilaian, dan pemecahan maslah. Menurut penelitian yang dilakukan oleh Panggabean, 2019 kemampuan berfikir kritis perawat dalam pengambilan keputusan klinis. Critical thinking dapat menginvestigasi terhadap tujuan guna mengeksplorasi situasi,fenomena,pertanyaan atau masalah untuk menuju pada hipotesa atau keputusan secara terintegrasi.Berpikir kritis dalam keperawatan merupakan komponen dasar dalam mempertanggung jawabkan profesi dan kualitas perawatan. Kesimpulannya adalah perawat yang berfikir kritis berpeluang besar untuk mampu melakukan tindakan keperawatan maupun asuhan keperawatan dengan baik jika dibandingkan dengan perawat yang kurang berpikir kritis dalam pengambilan keputusan melakukan tindakan dan asuhan keperawatan.
\end{abstract}

Key words : Pengambilan Keputusan,Berpikir Kritis, Pelayanan Kesehatan 


\section{Latar Belakang}

Menurut Levey dan

Loomba,Pelayanan Kesehatan ialah usaha untuk melangsungkan sendiri maupun secara berbarengan dalam suatu penataan kesehatan untuk menghindari dan mengembangkan kesehatan,menjaga dan mengobati penyakit di tiap masyarakat ataupun rakyat. Hubungan antara pasien dan perawat merupakan interaksi timbal balik dimana respon pasien dan perawat saling memengaruhi dan terus berkembang sejalan dengan perubahan respon antara pasien dan perawat. Salah satu fungsi profesionalitas perawat adalah menemukan kebutuhan pasien yang tidak terpenuhi dan kemudian memberikan bantuan untuk memenuhi kebutuhan tersebut. Proses keperawatan memfasilitasi perawat untuk berkembang sebagai seorang pemikir yang logis untuk menghasilkan peningkatan respon dan perilaku pasien dalam pemenuhan kebutuhannya serta pentingnya partisipasi pasien dalam keseluruhan proses (Stonehouse, 2017).

Sepanjang komponen dari proses keperawatan ,perawat menggunakan sikap dan kemampuan berfikir kritis untuk menentukan relevansi,makna dan iterrelasi data pasien serta untuk menetapkan asuhan keperawatan yang sesuai (Cristensen \& Kenney, 2009).Berpikir kritis juga dapat dikatakan sebagai konsep dasar yang terdiri dari konsep berpikir yang berhubungan dengan proses belajar dan kritis itu sendiri berbagai sudut pandang selain itu juga membahas tentang komponen berpikir kritis dalam keperawatan yang di dalamnya dipelajari karakteristik,proses,aplikasi berpikir kritis dan pengambilan keputusan yang etis dalam berpikir kritis. Kemampuan perawat mengidentifikasi masalah klien dan memilih solusi intervensi yang tepat tidak lepas dari kemampuan perawat berfikir kritis untuk menggali berbagai alasan berdasarkan evidence base dari setiap problem dan solusi yang teridentifikasi (Potter \& Perry, 2010).

Proses pengambilan keputusan klinis merupakan komponen penting dalam proses keperawatan sehingga dibutuhkan kemampuan perawatan karena keterbatasan pengetahuan dan kemampuan yang dimiliki perawat dapat menghambat perawat dalam mengambil keputusan mengenai perawatan yang akan diberikan kepada klien yang akan berakibat fatal terhadap klien (Kozier et al 2010). Pengambilan keputusan dalam praktik klinik keperawatan dipahami sebagai serangkaian keputusan yang dibuat oleh perawat dalam interaksinya dengan pasien mengenai jenis pengamatan yang akan dilakukan dalam situasi yang di alami klien (pengkajian keperawatan), perumusan diagnosa keperawatan, rencana tindakan 
keperawatan yang harus diambil, tindakan keperawatan yang akan diambil serta evaluasi (Dianan Catarina. 2009, JanFlorin. 2007, Mehee, 2014). Pengambilan keputusan sangat penting keberadaannya dalam asuhan maupun dalam manajemen keperawatan. Pengambilan keputusan merupakan suatu proses yang mencakup semua penilaian kegiatan yang diperlukan guna membuktikan dan meperlihatkan pilihan terbaik dalam menyelesaiakan suatu masalah tertentu. setiap keputusan adalah akibat dari sebuah proses dinamis yang dipengaruhi oleh banyak kekuatan, pengambilan keputusan. Yang terjadi di Indonesia pengambilan keputusan belum sepenuhnya dilakukan bersama antara perawat-klien. Perawat masih berperan sebagai pengambil keputusan tunggal. Sehingga dibutuhkan pemahaman lebih lanjut terkait dengan pengambilan keputusan klinis keperawatan dengan harapan peran perawat akan lebih terlihat nyata sebagai pemberi asuhan yang akan meningkatkan kepercayaan masyarakat terhadap profesi keperawatan

\section{Tujuan}

Tujuan dari penggambilan keputusan ialah untuk mengetahui konsep dan standar pengambilan keputusan bagi perawat secara kritis dalam pelayanan kesehatan untuk menghasilkan peningkatan respon dan perilaku pasien dalam pemenuhan kebutuhannya serta pentingnya partisipasi pasien dalam keseluruhan proses sehingga patient center care terimplementasikan secara maksimal.

\section{Metode}

Rancangan penugasan kajian ini menggunakan literature review berdasarkan jurnal,dan e-book (yang dipublikasikan 10 tahun terakhir) dan menggunakan dua belas sumber referensi dengan menganalisis, eksplorasi, dan kajian bebas sesuai dengan judul penugasan kajian ini.

\section{Hasil}

Dalam proses keperawatan hubungan perawat-klien sering rentan, karena perawat memiliki kekuatan lebih dari klien. Perawat memiliki pengaruh, akses, informasi, dan pengetahuanserta keterampilan khusus. Perawat memiliki kompetensi untuk mengembangkan hubungan terapeutik dan menetapkan batas-batas yang sesuai dengan kebutuhan Klien.Salah satu kompetensi yang dimaksud ialah kemampuan perawat menjadi seorang fasilitator bagi klien untuk mengambil keputusan secara kritis yang memiliki hambatan baik secara intelektual,bio,psiko,sosial. Tujuan dari partisipasi klien ialah untuk memnadirikan klien dalam mengambil keputusan sehingga meringankan beban kerja perawat dalam 
sumber daya.Ada 6 elemen dalam pengambilan keputusan :

$>$ Pengumpulan Data

$>$ Hipotesa

$>$ Rencana Kegiatan

$>$ Alternative

> Pemecahan Masalah

$>$ Asumsi

Sebagai fasilitator perawat harus memiliki standar -standar berupa:

1. Perawat harus mampu mengidentifikasi masalah klien dan memilih solusi intervensi yang tepat serta tidak lepas dari kemampuan perawat berpikir tingkat tinggi untuk menggali berbagai alasan berdasarkan evidence base dari setiap masalah dan solusi yang terindentifikasi

2. focus terhadap penyelesaian masalah dan membuat keputusan, serta tidak akan membuat keputusan yang terburu-buru ataupun ceroboh.

3. kompentisi perawat, kemampuan berkomunikasi, lingkungan serta budaya. Penting bagi perawat untuk selalu meningkatkan kapasitas dirinya dalam pemberian asuhan keperawatan hal ini akan meningkatkan kepercayaan masyarakat terhadap perawat yang selanjutnya akan meningkatkan profesionalisme perawat

\section{Pembahasan}

Proses pengambilan keputusan merupakan sebuah refleksi dari perawat ataupun klien, pengambilan keputusan klinis keperawatan harus ada interaksi antara perawat-klien, pengambilan keputusan klinis keperawatan dapat dilakukan dalam setiap proses keperawatan, tugas perawat pada saat proses pengambilan keputusan ini adalah sebagai fasilitator untuk memberikan fasilitas dan dukungan pada klien, pengambilan keputusan klinis dengan melibatkan klien akan meningkatkan tingkat kemandirian bagi klien, pengambilan keputusan klinis diperlukan kemampuan berfikir kritis bagi perawat. Terdapat 6 elemen-elemen yang terdapat dalam pengambilan keputusan adalah :

1) Pengumpulan Data

Proses ini meliputi pengumpulan informasi yang sistemik tentang klien. Tujuan melakukan pengumpulan data adalah menentukan kemampuan klien dalam memelihara diri sendiri, melengkapi data dasar untuk membuat rencana keperawatan, serta memberi waktu pada klien untuk berkomunikasi. Pengkajian ini meliputi aspek fisik, psikis, sosial, dan spiritual . Pengumpulan data dapat dilakukan melalui wawancara, observasi, dan pemeriksaan.Pengumpulan data dapat dilakukan dengan melibatkan keluarga atau penanggungjawab sebagai orang terdekat yang mengetahui masalah kesehatan.Data yang didapatkan dapat bersifat subjektif dan objektif . 
2) Hipotesa

adalah suatu pernyataan asumsi tentang hubungan antara dua atau lebih variabel yang diharapkan bisa menjawab suatu pertanyaan. Berdasarkan data awal tadi, perawat akan menyusun hipotesis yang memungkinkan dari masalah pasien tadi. Hipotesis ini akan membantu perawat untuk menjelaskan kemungkinan penyebab gangguan penyakit, gejala penyakit dan gangguan fungsional lainya yang terjadi pada pasien. Selanjutnya perawat menentukan diagnosis keperawatan dengan menguraikan respon individu terhadap proses penyakit yang dialami pasien yaitu masalah diagnosis yang actual dan potensial (Lee at al, 2016). Perawat harus mampu mengidentifikasi masalah klien dan memilih solusi intervensi yang tepat serta tidak lepas dari kemampuan perawat berpikir tingkat tinggi untuk menggali berbagai alasan berdasarkan evidence base dari setiap masalah dan solusi yang terindentifikasi (Potter \& Perry, 2010).

\section{3) Rencana Kegiatan}

Perawat mengembangkan rencana pelayanan yang berhubungan dan hal-hal yang berkaitan dengan tujuan, prioritas, serta pendekatan keperawatan yang digunakan dalam rencana perawatan termasuk di dalamnya kepentingan terapeutik, promotif, preventif, dan rehabilitatif.Rencana

keperawatan membantu klien memperoleh dan mempertahankan kesehatan pada tingkatan yang paling tinggi kesejahteraan dan kualitas hidup dapat tercapai, demikian jugahalnya untuk menjelang kematian secara damai. Rencana dibuat untuk keberlangsungan pelayanan dalam waktu yang tak terbatas, sesuai dengan respons atau kebutuhan klien. Hal-hal yang harus diperhatikan dalam menyusun rencana keperawatan :

a. Sesuaikan dengan tujuan yang spesifik di mana diarahkan pada pemenuhan kebutuhan dasar.

b. Libatkan klien dan keluarga dalam perencanaan.

c. Kolaborasi dengan profesi kesehatan yang terkait

d. Tentukan prioritas. Klien mungkin sudah puas dengan kondisinya, bangkitkan perubahan tetapi jangan dipaksakan, rasa aman dan nyaman adalah yang utama. e. Sediakan waktu yang cukup untuk klien f. Dokumentasikan rencana keperawatan yang telah dibuat.

\section{4 ) Alternatif}

Seperti yang telah dibahas sebelumnya bahwa pengambilan keputusan adalah pemilihan diantara alternatif-alternatif mengenai sesuatu cara bertindak. Demikian halnya dalam pengambilan keputusan tindakan dalam keperawatan, perawat mengkaji data pasien dan menemukan 
beberapa alternatif tindakan keperawatan hingga memutuskan tindakan yang tepat dari beberapa alternatif tersebut sebagai keputusan yang paling tepat yang berdampak baik untuk menunjang kesembuhan pasien tersebut.

\section{5) Pemecahan Masalah}

Sebagai seorang perawat proses keperawatan dapat digunakan sebagai pedoman dalam pemecahan masalah klien, dapat menunjukkan profesi yang memiliki profesionalitas yang tinggi, serta dapat memberikan kebebasan pada klien untuk mendapatkan pelayanan yang cukup sesuai dengan kebutuhannya (Aziz Alimul $\mathrm{H}$, 2004).Perawat mengimplementasikan rencana asuhan keperawatan untuk mencapai tujuan yang telah ditetapkan dan partisipasi klien dalam tindakan keperawatan pada hasil yang diharapkan. Perawat memberikan pelayanan kesehatan yang memelihara kemampuan fungsional kliendan mencegah komplikasi serta meningkatkan ketidakmampuan. Tindakan keperawatan berdasarkan rencana keperawatan dari setiap diagnosis keperawatan yang telah dibuat dengan didasarkan pada konsep asuhan keperawatan

6) Asumsi

Perawat menggunakan berbagai kemampuan dalam memutuskan efektif atau tidaknya pelayanan keperawatan yang diberikan. Untuk memutuskan hal tersebut dalam melakukan evaluasi seorang perawat harus mempunyai pengetahuan tentang standar pelayanan, respon pasien yang normal, dan konsep model teori keperawatan. Praktik keperawatan merupakan suatu proses dinamis yang mencakup berbagai perubahan data, diagnosa atau perencanaan yang telah dibuat sebelumnya. Efektivitas asuhan keperawatan tergantung padam pengkajian yang berulang - ulang. Dalam melakukan proses evaluasi, ada beberapa kegiatan yang harus diikuti oleh perawat, antara lain: 1. Mengkaji ulang tujuan klien dan kriteria hasil yang telah ditetapkan

2. Mengumpulkan data yang berhubungan dengan hasil yang diharapkan

3. Mengukur pencapaian tujuan

4. Mencatat keputusan atau hasil pengukuran pencapaian tujuan

5. Melakukan revisi atau modifikasi terhadap rencana keperawatan bila perlu (Lee at al, 2016)

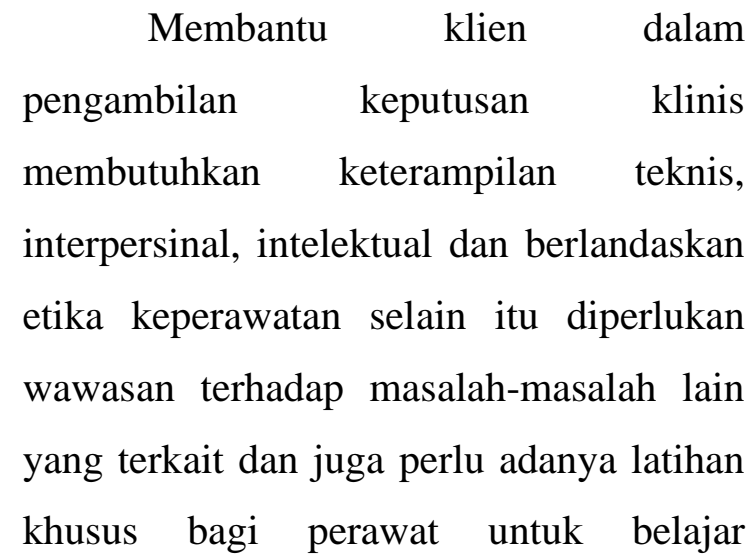


mengambil keputusan klinis terkait dengan konsep terkait (Samijatun, 2009). Hubungan perawat-klien adalah suatu hubungan interpersonal yang profesional dan terapeutik dengan tujuan memenuhi kebutuhan klien. Hubungan profesional perawat dan klien didasarkan pada pemahaman bahwa klien adalah orang yang paling tepat untuk membuat keputusan Keterlibatan klien yang dimaksud dalam pengambilan keputusan ini adalah sebagai upaya pemberdayaan klien sehingga meningkatka tingkat kemandirian klien sebagaimana dijelaskan dalam teori Dorothea Orem (1980): self care dimana konsep ini menekankan pada perawatan diri secara mandiri, kemandirian dipandang sebagai bentuk praktik kebiasaan/tingkah laku yang dilakukan oleh klien dalam mepertahankan kesehatan dan kondisinya (Jaan Florin 2007,Samijatun 2009 dan Aligood, 2012).Tingkat kemandirian ini akan dicapai jika pasien dan keluarga mampu mengambil keputusan dengan baik dan tepat dalam memilih asuhan dan bantuan terkait kondisinya. Sehingga diperlukan peran aktif pasien dan keluarga dalam pengambilan keputusan klinis tersebut. Dalam beberapa penilitian disebutkan bahwa tugas perawat pada saat pengambilan proses pengambilan keputusan ini adalah sebagai fasilitator untuk memberikan fasilitas dan dukungan pada klien (Jan Florin 2007 dan paaulina Bravo. 20115).

Perawat yang menerapkan pemikiran kritis dalam bekerja akan focus terhadap penyelesaian masalah dan membuat keputusan, serta tidak akan membuat keputusan yang terburu-buru ataupun ceroboh (Kataoka-Yahiro dan Saylor, 1994). Perawat yang bekerja dalam situasi kritis seperti di unit gawat darurat sering bertindak terlalu cepat pada saat ada masalah. Namun, perawat tersebut telah berlatih disiplin dalam membuat suatu keputusan untuk menghindari keputusan yang terlalu cepat dan tidak tepat. Ada juga beberapa karakteristik berpikir kritis yaitu :

Konseptualisasi

Konseptualisasi artinya proses intelektual membentuk suatu konsep.

Rasional dan Beralasan

Artinya argument yang diberikan selalu berdasarkan analisis dan mempunyai dasar kuat dari fakta fenomena nyata.

\section{Reflektif}

Artinya bahwa seorang pemikir kritis tidak menggunakan asumsi atau persepsi dalam berpikir atau mengambil keputusan tetap akan menyediakan waktu untuk mengumpulkan data dan menganalisisnya berdasarkan disiplin ilmu, fakta dan kejadian.

\section{Berpikir adil dan Terbuka}

Yaitu mencoba untuk brubah dari pemikiran yang salah dan kurang 
menguntungkan menjadi benar dan lebih baik.

Cara untuk meningkatkan kemampuan berpikir kritis diantaranya pertama adalah membaca dengan kritis. Untuk berpikir secara kritis, seorang perawat harus bisa membaca dengan kritis pula dalam hal itu penting juga kita mengetahui bagaimana aplikasi berpikir kritis dalam keperawatan yaitu :

Interpretasi

Analisis

Kesimpulan

Evaluasi

Penjelasan

Pengontrolan diri

Tanggung jawab utama saat membina hubungan kolaborasi perawatklien adalah bahwa perawat berperan sebagai leader dalam pengambilan keputusan klinis keperawatan. Pengalam pasien dalam keterlibatan proses keperawatan harus dihargai dan dapat digunakan sebagai dasar dalam pengambilan keputusan klinis. Perawat harus memahami kebutuhan klien dalam setiap proses keperawatan, sehingga hubungan perawat klien dalam pengambilan keputusan dapat dilakukan dalam setiap proses keperawatan. Ketepatan pengambilan keputusan akan di pengaruhi oleh kompentisi perawat, kemampuan berkomunikasi, lingkungan serta budaya. Penting bagi perawat untuk selalu meningkatkan kapasitas dirinya dalam pemberian asuhan keperawatan hal ini akan meningkatkan kepercayaan masyarakat terhadap perawat yang selanjutnya akan meningkatkan profesionalisme perawat. Hal ini bisa digunakan sebagai acuan dalam melakukan hubungan interdisiplin. Pengambilan keputusan yang tepat akan meningkatkan kemandirian klien dalam asuhannya serta membantu klien untu menentukan pilihan bantuan yang tepat sesuai dengan kondisinya. Klien yang mandiri akan menurunkan beban kerja perawat sehingga pelayanan keperawatan akan lebih efektif dan efisien dalam penggunaan sumber daya. Untuk itu dibutuhkan banyak dukungan dalam implementasi shared clinical decision making ini, misal dibuatkannya SPO pengambilan keputusan klinis keperawatan, meningkatkan sumber daya perawat dengan menciptakan perawat yang caring perawat yang peka budaya perawat memperhatikan etik, disiplin dan bioteik keperawatn dalam setiap asuhannya sebagai upaya untuk meningkatkan kemampuan berkomunikasi memberikan dukungan kepada pasien, sehingga dubutuhkan PKB (Pendidikan Keperawatan Berkelanjutan) atau dengan sistem preseptorship untuk membentuk perawat yang kompeten, mempunyai kemampuan critical thinking dalam 
pengambilan keputusan klinis keperawatan.

Organisasi profesi mempunyai peranan yang penting dalam mewujudkan perawat yang kompeten dalam melakukan pengambilan keputusan klinis keperawatan.

\section{Penutup}

Hubungan perawat-klien adalah suatu hubungan interpersonal yang profesional dan terapeutik dengan tujuan memenuhi kebutuhan klien.Partisipasi pasien dalam pelayanan kesehatan sangat penting untuk diimplementasikan.Salah satunya yaitu partisipasi pasien dalam pengambilan keputusan secara kritis.Adanya keterbatasan pengetahuan menjadi hambatan bagi pasien untuk menggambil keputusan sehingga yang terjadi ialah perawat menjadi pengambil keputusan tunggal.Pada kondisi ini diharapkan perawat dapat menjadi fasilitator bagi pasien atau klien dalam menggambil keputusan secara kritis.Sebagai fasilitator dalam pengambilan keputusan secara kritis perawat juga memiliki beberap standar yaitu

1. Perawat harus mampu mengidentifikasi masalah klien dan memilih solusi intervensi yang tepat serta tidak lepas dari kemampuan perawat berpikir tingkat tinggi untuk menggali berbagai alasan berdasarkan evidence base dari setiap masalah dan solusi yang terindentifikasi
2. focus terhadap penyelesaian masalah dan membuat keputusan, serta tidak akan membuat keputusan yang terburu-buru ataupun ceroboh.

3. kompentisi perawat, kemampuan berkomunikasi, lingkungan serta budaya. Penting bagi perawat untuk selalu meningkatkan kapasitas dirinya dalam pemberian asuhan keperawatan hal ini akan meningkatkan kepercayaan masyarakat terhadap perawat yang selanjutnya akan meningkatkan profesionalisme perawat.

Keberhasilan dari proses penggambilan keputusan secara kritis dapat dilihat dari kemandirian klien yang akan menurunkan menurunkan beban kerja perawat sehingga pelayanan keperawatan akan lebih efektif dan efisien dalam penggunaan sumber daya.

\section{Daftar Pustaka}

Arli. K.S, (2017). Critical Thinking and

Caring in Nursing Students. International Journal Of Caring Sciences, 10(1), 471478.

DS,Bambang Sudono,dkk. (2017) Gambaran Kemampuan Berpikir Kritis Perawat Primer Dalam Pelaksanaan Asuhan Keperawatan di Rumah Sakit Islam Surakarta.Jurnal Ilmu Keperawatan Indonesia.10(1).88-100 
Indriate .(2013).Berpikir Kritis dalam

Proses Keperawatan.Jurnal Keperawatan $.6(2) .89-90$

Khairina,I Malini,E,\& Huriani,E.(2018).

Faktor-Faktor Yang Berhubungan Dengan

Pengambilan Keputusan Perawat Dalam Ketepatan Triase Di Kota Padang. Indonesian Journal for Health Sciences.2(1): 1-2

Pashar,I. \& Luki ,D.(2020). Pengaruh Empowerment Terhadap Pengambilan Keputusan Perawat: Kajian Literature Review. JOURNAL OF HOLISTIC NURSING SCIENCE.7(2): 126

Patmawati, dkk (2018). Efektifitas Metode Pembelajaran Klinik Terhada Kemampuan Berpikir Kritis dan Kepercayaan Diri Mahasiswa Keperawatan. Jurnal Keperawatan Muhammadiyah, 3(2), 89-92

Rahayu,C.D, \& Mulyani,S.(2020). Pengambilan Keputusan Klinis Perawat. Jurnal Ilmiah Kesehatan.3(2): 3-7

Redhana,I.W.(2013).Model Pembelajaran Berbasis Masalah untuk Peningkatan Keterampilan Pemecahan Masalah dan Berpikir Kritis.Jurnal Pendidikan dan Pengajaran.1(46): 77-80
Ridwan,dkk.(2014).Efektivitas Organisasi Pelayanan Keperawatan Berdasarkan Komunikasi,Pengambilan

Keputusan,Sosialisasi Karir,dan Jenjang Karir.Journal Keperawatan Indonesia $.13(1): 2-4$

Simamora, R. H. (2019). Menjadi perawat yang: CIH'HUY . Surakarta: Kekata Publisher .

Simamora, R. H. (2005). Hubungan Persepsi Perawat Pelaksana Terhadap Penerapan Fungsi Pengorganisasian Yang Dilakukan Oleh Kepala Ruangan Dengan Kinerjanya Diruang Rawat Inap RSUD Koja Jakarta Utara (Doctoral dissertation, Tesis FIK UI, Tidak dipublikasikan).

Yurista, D., Bakar, A., \& Mirza, M. (2018). Hubungan Antara Kecerdasan Emosi Dengan Stres Kerja Pada Perawat. Journal Psikogenesis, $\quad 5(1), \quad$ 42-46. https://doi.org/10.24854/jps.v5i1.495 